\title{
DEVELOPING THE TRANSMISSION SYSTEM OF THE COMBINE CUTTING DEVICE FOR HARVESTING RICE CROP
}

\author{
Helmy M. A.*, T. Z. Fouda**, A. Derbala*** and H. A. Kassem*****
}

\section{ABSTRACT}

The transmission system of the combine cutting device was developed and manufactured from local material to be suitable for the harvesting operation under Egyptian conditions. Performance evaluation of the combine before and after development during the harvesting operation of rice crop was carried out in terms of grain losses, field capacity, field efficiency, fuel consumption, required power, energy, wearing rate, wearing resistance and cost requirements. The combine performance was studied as a function of change in combine forward speed and grain moisture content and operating time. The results were obtained to gave maximum field capacity, field efficiency, wearing resistance and minimum energy, power, fuel consumption wearing rate, and cost requirements for the two systems of the combine cutting device before and after development as following:

1- It is recommended to used the developed combine.

2- The combine forward speed of about $3.5 \mathrm{~km} / \mathrm{h}$.

3- The grain moisture content about $23 \%$.

\section{INTRODUCTION}

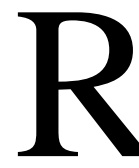

ice crop is considered one of the most important foods and export crops in Egypt. The cultivated area of rice in Egypt is about 1.77 average yield of 4.091 tons/ feddan according to Ministry of Agriculture statistics (2009) Habib et al. (2001) mentioned that increasing plant stem diameter need higher knife velocity for performing the free cutting

\footnotetext{
* Prof., of Agric. Eng., Fac. of Agric., Kafr-elsheikh U. ** Prof., of Agric. Eng., Fac. of Agric., Tanta U. *** Assoc. Prof., of Agric. Eng., Fac. of Agric., Tanta U. **** Grad. St. Ag. Mec. Dept., Fac. of Agric., Tanta U.
} 
operation. Whereas, increasing mass of plant stalks need low critical speed. Also, moisture content of plants materials affecting on the critical knife velocity throwing by the cutting force, where the cutting force variation with the moisture content. El-Nakib et al. (2003) found that header, threshing, separating and shoe losses increased with the increase of the forward speed and the decrease of grain moisture content. The optimum operating parameters for harvesting rice crop were, combine forward speed of $4.5 \mathrm{~km} / \mathrm{h}$ and grain moisture content of $16.5 \%$.

Badr et al. (2005) indicated that increasing the forward speed from 1.0 to $4.0 \mathrm{~km} / \mathrm{h}$ at a constant moisture content of $22 \%$, increased field capacity from 0.31 to $1.14 \mathrm{fed} / \mathrm{h}$ while decreased field efficiency from 89.3 to 82.7 $\%$ using Yanmar combine. El- Sharabasy (2006) tested that increasing machine forward speed from 1.5 to $3.0 \mathrm{~km} / \mathrm{h}$ increased effective field capacity from 0.277 to $0.452,0.251$ to $0.382,0.208$ to 0.349 and 0.181 to $0.296 \mathrm{fed} / \mathrm{h}$ at different grain moisture contents of 21.45, 22.20, 23.12 and $24.60 \%$, respectively. Fouda and El-tarhuny (2007) studied that the wearing behavior are affecting by many factor such as composition of material, hardness, strength, toughness and working time. Also, they added that increasing working time increased wearing rate. Abdelmotaleb et al.(2009) showed that the increase of combine forward speed forward 0.8 to $2.5 \mathrm{~km} / \mathrm{h}$ leads to decrease the field efficiency from 84.96 to $62.35 \%$ at cutting height of $0.2 \mathrm{~m}$ by using the combine without control system. The other cutting heights and combine systems had the same above mention trend. El-Hanfy et al. (2009) studied that the power consumption for cutting straw rice was increased with increasing forward speed and cutting speed. The minimum value of power consumption was $(15 \mathrm{~kW})$ noticed at $(0.35 \mathrm{~m} / \mathrm{sec}$ and $450 \mathrm{rpm})$ forward and cutting speed respectively.

So one of the serious problems during the harvesting operation were noticed that the vibration in the transmission system of the combine cutting device which causes to high wearing rate and break the crank.

-The objectives of the present work are developing the cutting blade crank of the combine for harvesting rice crop and selecting the combine optimum conditions. Also estimate the expected life for the cutting blade crank before and after development. 


\section{MATERIALS AND METHODS}

The main experiments were carried out during seasons 2007 and 2008 at Bassuen farm, Gharbia Governorate to develop the cutting blade crank on the Yanmar combine for harvesting rice crop (Sakha 101 variety) and select the optimum conditions (combine forward speed and grain moisture content) for operating the developed combine.

\section{-Materials :}

-The mean values of crop characteristics of rice variety Sakha 101 were plant height, $92.3 \mathrm{~cm}$, no. of panicles $526.5 / \mathrm{m}^{2}$ and weight of 1000 grain, $29.18 \mathrm{gm}$

-Combine harvester (Yanmar), Type (CA- 385 EG. Japan), output power hp/rpm, 35/2800 and engine vertical, water cooled 4-cyclediese.

\section{-Methods:}

The experiments were conducted in an area of 5 feddans at different forward speeds of 2, 2.5, 3.5 and $5 \mathrm{~km} / \mathrm{h}$ and grain moisture contents of $15,20.3,23$ and $25.7 \%$ during operating time (250, 500, 750 and 1000 hours) to select the operational optimum operational conditions.

-The combine cutting device: The combine cutting device in the Yanmar combine is a three dimensional - slider crank six bar mechanism. This mechanism is used to drive the combine cutters. It consists of crank shaft, connecting rod (pitman), lever, link and knife. Such problems had been noticed during the harvesting operation using the ordinary cutting mechanism. By many observation, it is noticed that the crank shaft of the cutting mechanism is the source of these problems. The wearing rate in the crank joints is very high, causes high vibration in the whole cutting mechanism parts that tends to break the crank. For this reason, such core had been taken to construct, develop and operate another crank taking into consideration cutting efficiency and crank durability.

\section{- Crank shaft of the cutting mechanism before development.}

Crank cutting blade unit was made of hard steel metal, the unit consists of yoke crank jointed with the rod reap edge crank and at the end there is a ball connected with arm reaping edge trans the motion to cutting blade. as shown in Fig 1 


\section{- Crank shaft of the cutting mechanism after development.}

The developed crank is constructed in such a case to avoid vibration of the cutting device and to prevent any loss of knife speed. The developed cutting device has a new design with two flange bearings. The device consists of holder bearing, bearing ball, nut, Shaft connect, holder bearing and bearing ball. The design was used to control the knife speeds and minimize the wearing rate of this part as shown in Fig 2.

Evaluation of the combine performance was carried out taking into consideration the following indicators:

-Effective field capacity: is the actual average working rate of area and theoretical field capacity is calculated by multiplying machine forward speed by the effective working width of the machine.

-Total grain losses: The percentage of total grain losses was calculated by using the following equation:-

Total grain losses $=$ (pre harvest + header + un cutting + threshing and cleaning.) losses, (\%)

-Required power: To estimate the engine power during harvesting process, the decrease in fuel level accurately measuring immediately after each treatment. Hunt equation (1983) was used to estimate the engine power.

-Wearing rate :was calculated as a removal weight g., or removal area from cutting device divided by operating time h., or , area $\mathrm{m}^{2}$, or harvest length $\mathrm{km}$.

\section{-Wearing resistance}

was calculated as inverted wearing rate (Kantarc 1982)

$$
\text { Wearing resistance, }\left(\mathrm{km} \cdot \mathrm{g}^{-1}\right)=\frac{1}{\text { Wearing rate },\left(\mathrm{g} \cdot \mathrm{km}^{-1}\right)}
$$

-Harvesting cost: The total cost of harvesting operation was estimated using (Awady, 1982) equation. The criterion cost was estimated by the following equation :-

Criterion cost/fed. $=$ operating cost + grain losses cost/fed. 


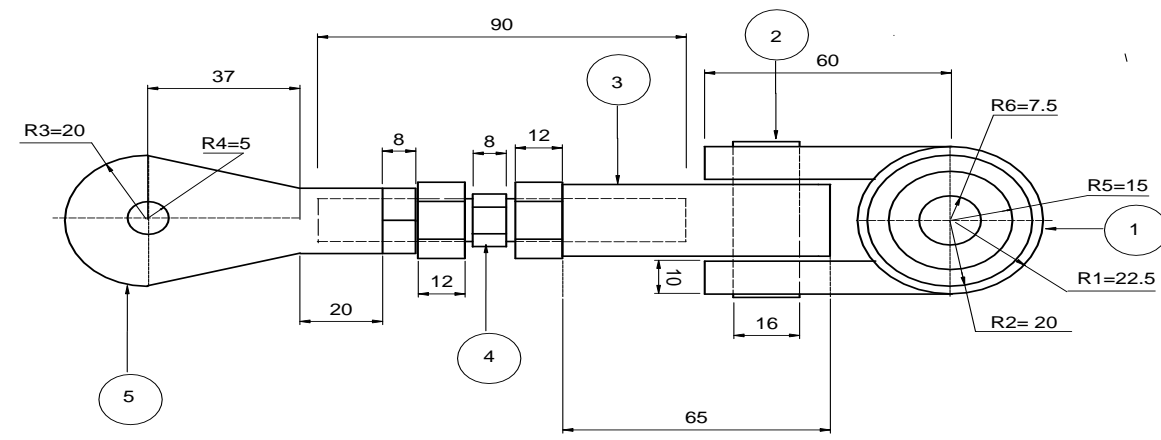

Fig. 1: Crank of the cutting device before development

\begin{tabular}{|c|l|c|l|}
\hline S. NO. & \multicolumn{1}{|c|}{ Part name } & S. NO. & \multicolumn{1}{c|}{ Part name } \\
\hline 1 & Yoke crank & 2 & Pin yoke \\
\hline 3 & Joint rod & 4 & Lock nut \\
\hline 5 & Ball rbl & & \\
\hline
\end{tabular}

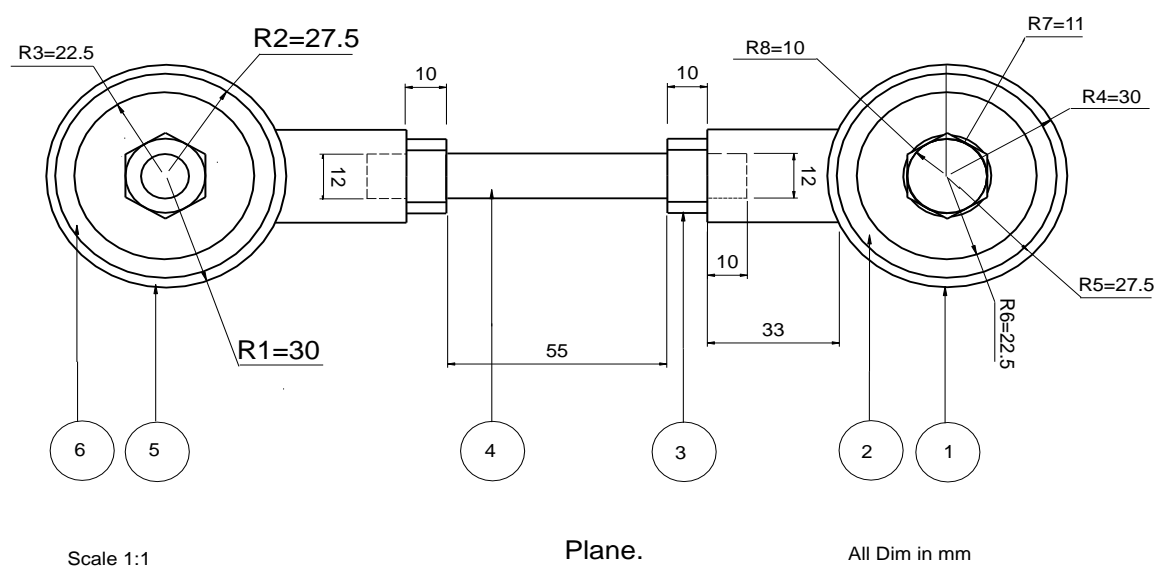

Fig. 2: Crank of the cutting device after development

\begin{tabular}{|c|l|c|l|}
\hline S. NO. & \multicolumn{1}{|c|}{ Part name } & S. NO. & \multicolumn{1}{c|}{ Part name } \\
\hline 1 & Holder bearing-L & 2 & Bearing ball \\
\hline 3 & Nut & 4 & Connecting rod \\
\hline 5 & Holder bearing-R & 6 & Bearing ball \\
\hline
\end{tabular}




\section{RESULTS AND DISCUSSIONS}

\section{-Effect of grain moisture content}

The most critical factor causing un-cutting losses is grain moisture content. Figs. 3 and 4 show the effect of grain moisture content on the percentage of un-cutting and total losses. The increase of grain moisture content less than $23.0 \%$ leads to increase the un-cutting and total losses. Also, the increase of grain moisture content more than $23.0 \%$ leads to increase the un-cutting and total losses due to increase un-cutting plants. Increasing the grain moisture content more than 23.0 up to $25.7 \%$ insignificantly affects the un-cutting and total losses. Therefore the lowest un-cutting and total losses values were recorded with the rice moisture content of $23 \%$. Also, The increase of un-cutting and total losses by increasing forward speed is due to decrease the cutting efficiency and increase un-cutting plants.

\section{- Effect of combine forward speed}

The effect of forward speed on field capacity and field efficiency shown in Fig. 5. The results revealed that by increasing of forward speed from 2 to $5 \mathrm{~km} / \mathrm{h}$. at a constant grain moisture content of $23 \%$ and operating time of $750 \mathrm{~h}$. the field capacity increased from 0.59 to $1.34 \mathrm{fed} / \mathrm{h}$. and from 0.61 to $1.35 \mathrm{fed} / \mathrm{h}$. before and after cutting device development respectively. While, increasing forward speed from 2 to $5 \mathrm{~km} / \mathrm{h}$. decreased field efficiency from 85.5 to $77.5 \%$ and from 88.4 to $78 \%$ under the same previous conditions. However, the high field efficiency of the modified combine may be due to higher actual field capacity comparing the original combine. Power as well as energy requirements are too related to the combine forward speed. Results show that, power required increased as the forward speed increased while the vice versa was noticed with energy requirements as shown in Fig. 6. The results evident that by increasing forward speed from 2 to $5 \mathrm{~km} / \mathrm{h}$ at a constant grain moisture content $23 \%$ and operating time of $750 \mathrm{~h}$ required power increased from 13.62 to14.47 $\mathrm{kW}$ and from 13.15 to14.28 $\mathrm{kW}$ before and after development respectively. The increase in required power by increasing combine forward speed is attributed to the excessive load of plants on the cutter- 
bar in the time unit and the high impact of cutter-bar with the plants added to the excessive load of plants on the other combine devices. Also, by increasing forward speed from 2 to $5 \mathrm{~km} / \mathrm{h}$. energy requirements decreased from 23.08 to $10.80 \mathrm{~kW} . \mathrm{h} / \mathrm{fed}$ and from 21.56 to.10.58 $\mathrm{kW} . \mathrm{h} / \mathrm{fed}$ under the same previous conditions. The decrease in energy requirements by increasing combine forward speed is attributed to the increase in field capacity.

\section{- Wearing rate and wearing resistance on cutting device}

The effect of operating time on wearing rate and wearing resistance in combine cutting device before and after development shown in Fig. 7. Results indicated that by increasing operating time from 250 to $1000 \mathrm{~h}$. the wearing rate in combine cutting device increased from 0.044 to 0.062 $\mathrm{g} / \mathrm{h}$ and from 0.03 to $0.04 \mathrm{~g} / \mathrm{h}$ before and after development respectively. While the wearing resistance decreased from 79.5 to $56.45 \mathrm{~km} \cdot \mathrm{g}^{-1}$ and from 116.7 to $87.5 \mathrm{~km} . \mathrm{g}^{-1}$ at the same condition.

\section{- Harvesting cost :}

The effect of combine forward speed on operating and criterion cost before and after development shown in Fig. 8. Results showed that increasing forward speed from 2 to $5 \mathrm{~km} / \mathrm{h}$ at a constant grain moisture content $23 \%$ and operating time of $750 \mathrm{~h}$ operating cost decreased from 101.64 to 44.78 L.E./fed. and from 98.36 to 44.44 L.E./fed. before and after development respectively. The higher values of operating cost at lower forward speed is due to the decrease in combine field capacity. While by increasing forward speed from 2 to $3.5 \mathrm{~km} / \mathrm{h}$ the criterion cost decreased from 214.92 to 198.19 L.E*./fed** and from 201.89 to 175.42 L.E./fed., increase in forward speed from 3.5 to $5 \mathrm{~km} / \mathrm{h}$ criterion cost will increase from 198.19 to 215.7 L.E./fed. and from 175.42 to 201.14 L.E./fed under the same previous conditions.

\footnotetext{
* One American dollar =5.54 Egyptian pound (LE) according to prices of 2010 $* *$ One feddan (fed) represents an agricultural area unit in Egypt $=4200.83 \mathrm{~m}^{2}$.
} 

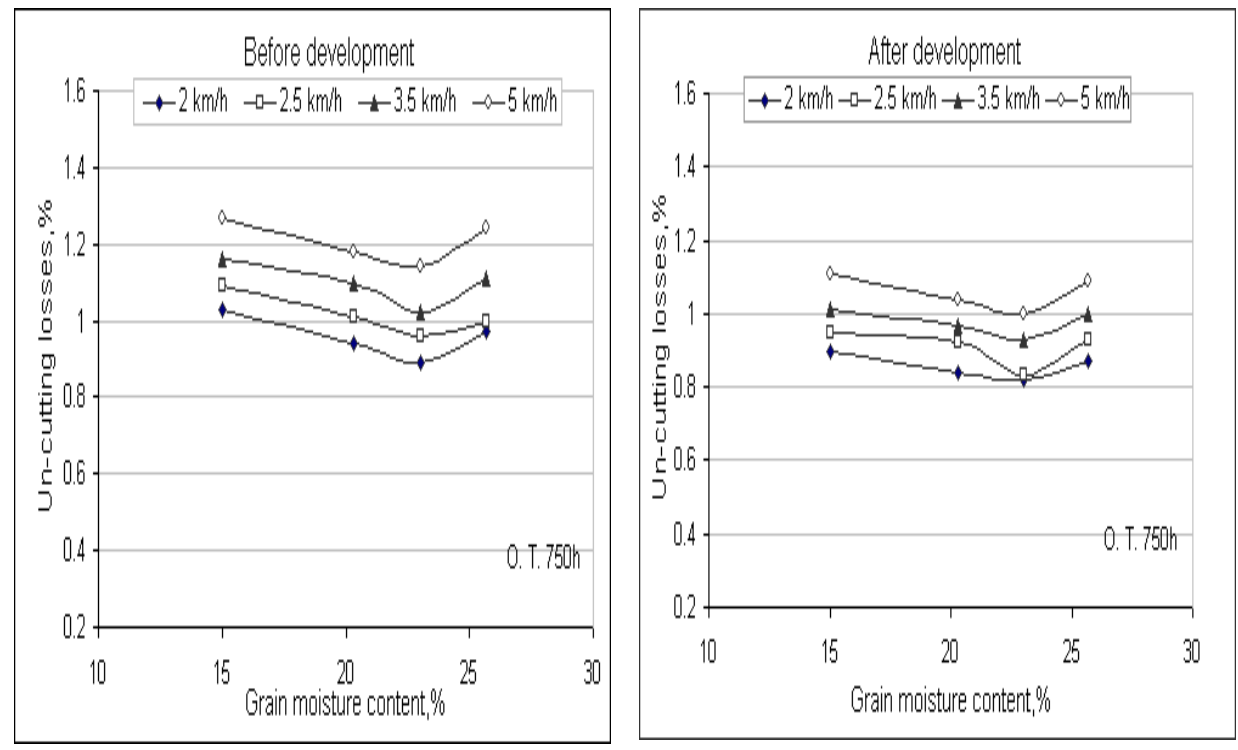

Fig. 3: Effect of grain moisture content on un-cutting losses under different forward speeds before and after cutting device development.
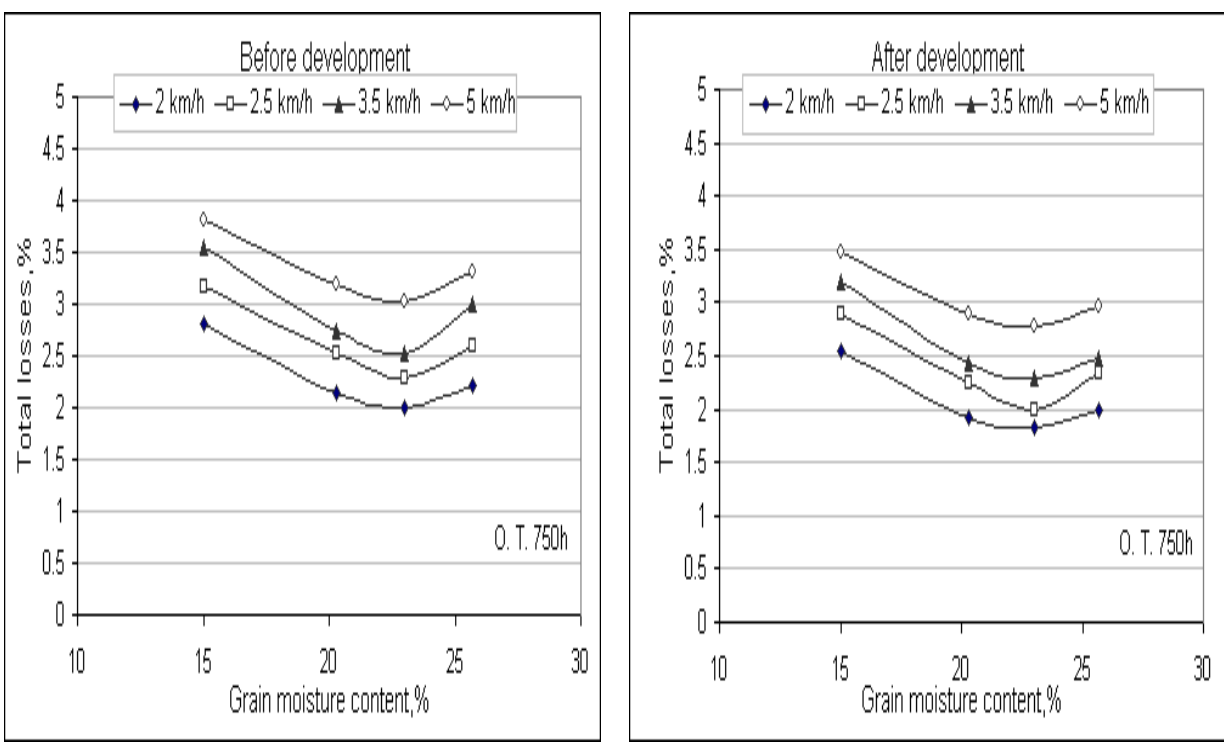

Fig. 4: Effect of grain moisture content on total grain losses under different forward speeds before and after cutting device development. 

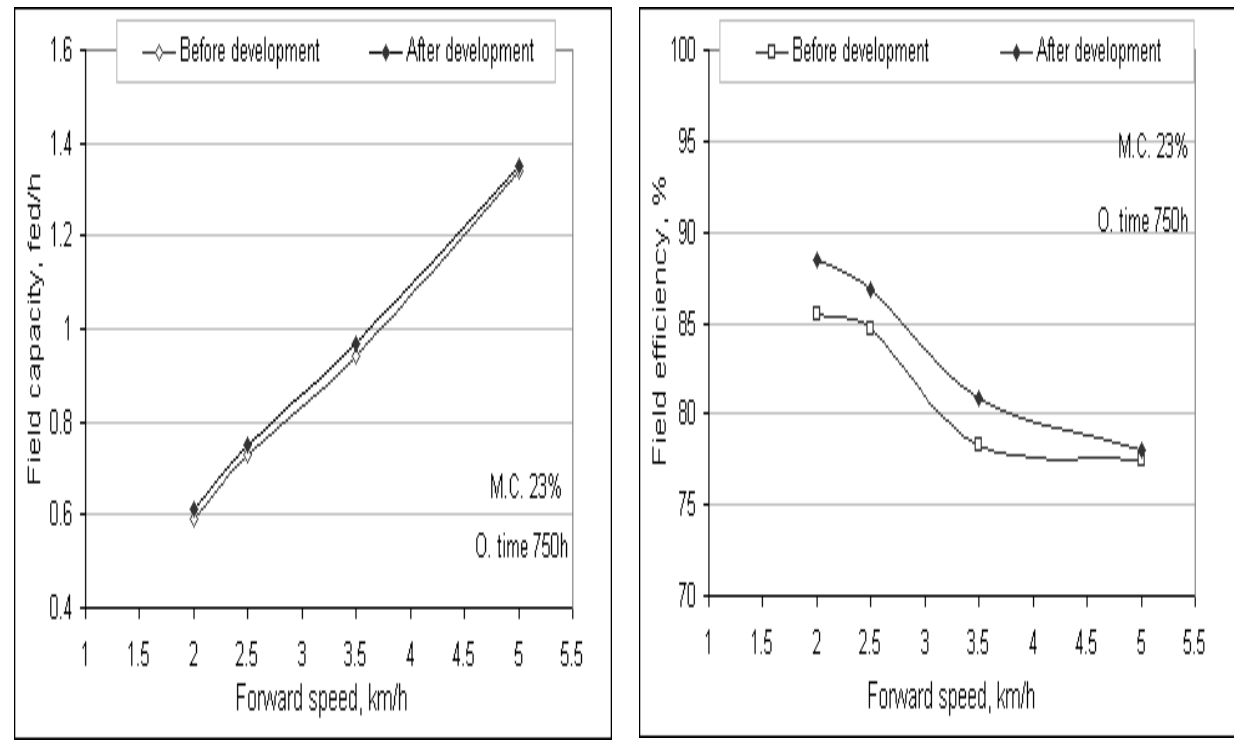

Fig. 5: Effect of combine forward speed on field capacity and field efficiency before and after cutting device development.
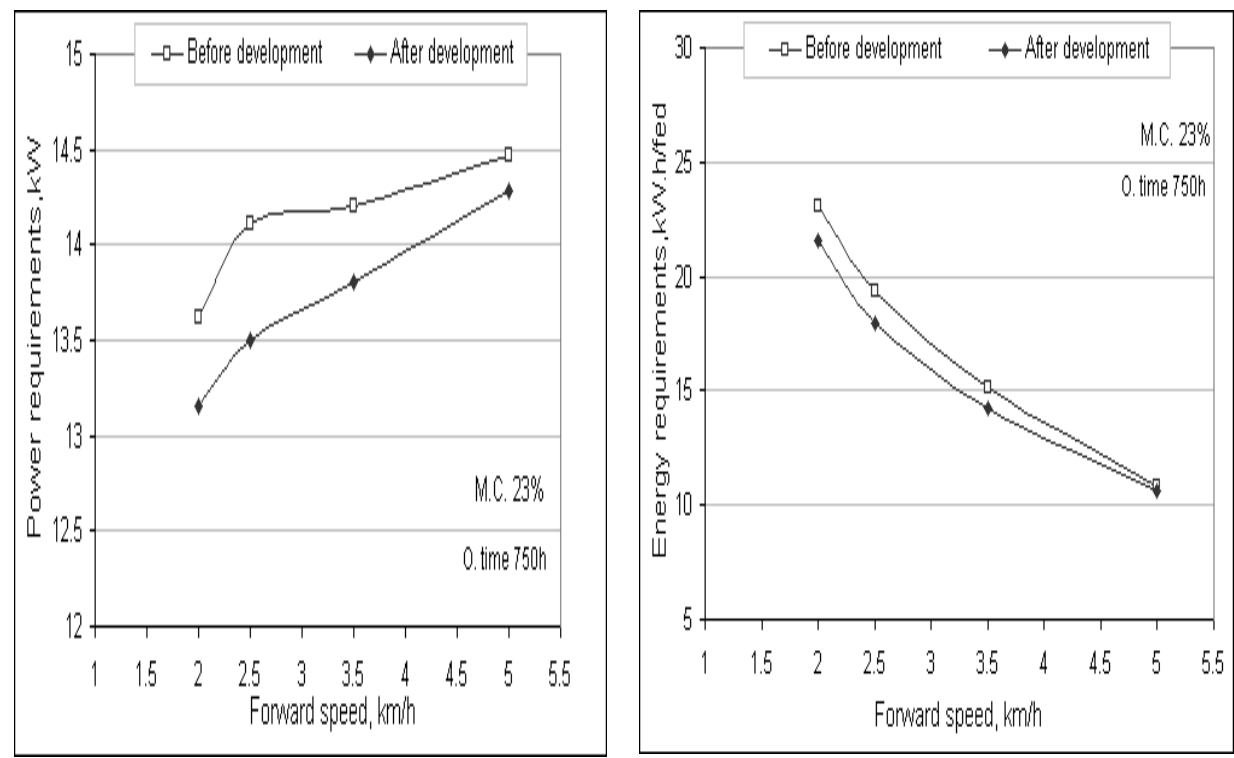

Fig. 6. Effect of combine forward speed on required power and energy requirements before and after cutting device development. 

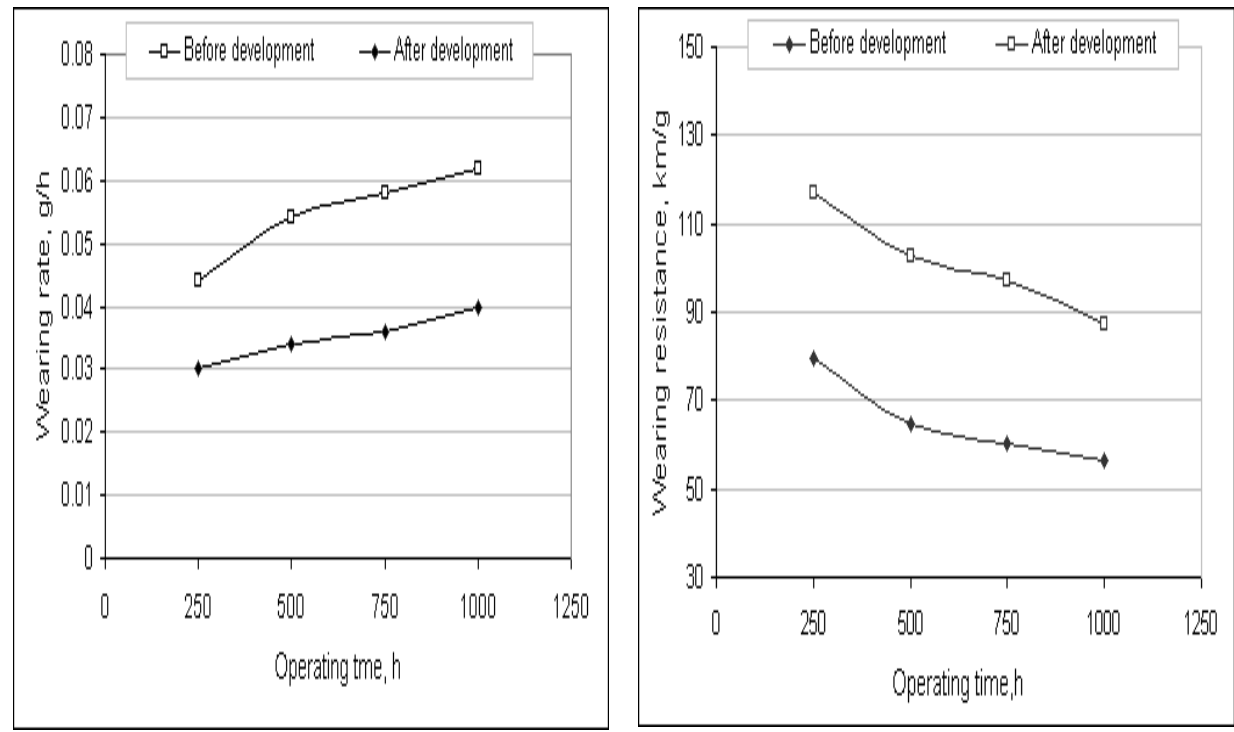

Fig.7: Effect of operating time on wearing rate in combine cutting device before and after development.
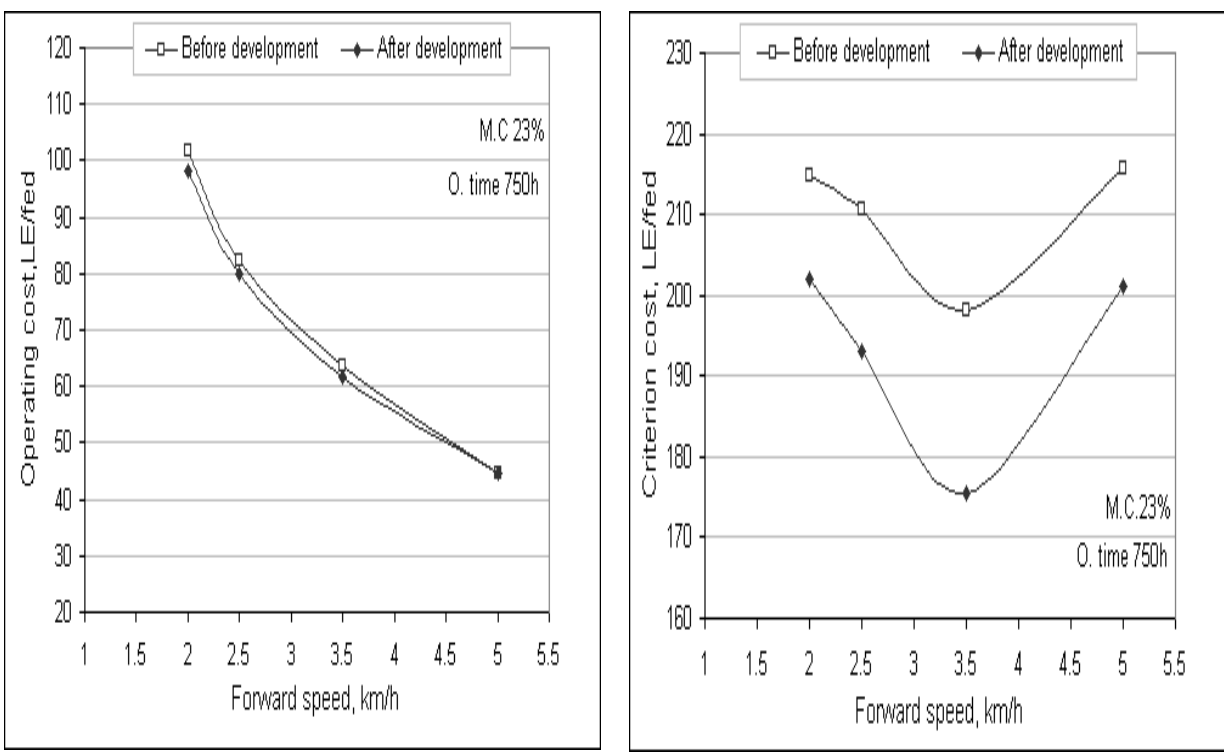

Fig.8: Effect of combine forward speed on operating and criterion cost before and after cutting device development. 


\section{CONCLUSION}

The main results of the present research can be summarized as follows:

-The development of the combine cutting device during harvesting rice crop gave to maximum field capacity, field efficiency, wearing resistance and minimum required power, energy, wearing rate and cost requirements.

-The optimum conditions for operating the combine during harvesting rice crop, were forward speed of $3.5 \mathrm{~km} / \mathrm{h}$., operating time of $750 \mathrm{~h}$ and rice grain moisture content of $23 \%$.

\section{REFERENCES}

Abdelmotaleb, I. A.; H. A. El-Gendy and M. A. Hassan (2009). Combine header control. Misr J.of Ag. Eng., 26(3): 1478-1500.

Awady, M. N. (1978). Tractor and farm machinery. Textbook, Faculty of Agriculture, Ain-Shams University.: 164-167.

Badr, M. M. (2005). Comparative study between some different combine sizes in respect to unit plot area. M.Sc. Thesis. Agric. Eng. Dept., Faculty of Agric., Zagazig Univ. Egypt.

El-Hanfy, E. H. and S. A. Shalby (2009). Performance evaluation and modification of the Japanese combine chopping unit. Misr J.of Ag. Eng., 26 (2): 1021-1035.

El-Nakib, A. A; Z. Y. Abdel-Lateef, A. A. El-Messery and A. Khattab (2003). Mechanical harvesting losses in rice crop using combine harvester. Misr J. Ag. Eng., 20 (4): 889-907.

El-Sharabasy, M. M. A. (2006). Construction and manufacture a self propelled machine suits for cutting some grain crops to minimize losses and maximize efficiency. Misr J. Ag. Eng., 23(3):509-531.

Fouda, T. and M. El-Tarhuny (2007). A study on plough shares wearing behavior under conditions of sandy loam soil. Misr J. Ag. Eng., 24(4):831-848.

Habib, R. A.; B. S. Azzam; G. M. Nasr and A. A. Khattab (2001). A theoretical analysis of the " free-cutting process" of plant materials. $1^{\text {st }}$ International conference for Manufacturing Agricultural Equipment and Machinery. $9^{\text {th }}$ Conference of Misr Society of Agric. Eng., 9-11 September. 
Hunt, D. (1983). Farm power and machinery management. $8^{\text {th }}$ Ed. Iowa State Univ., Press Ames, Iowa, USA: 364-368.

Kantarc (1982) Abrasive wear in tillage equipment. $\mathrm{PhD}$ degree thesis I. T. U. Izmir Univ. Turky

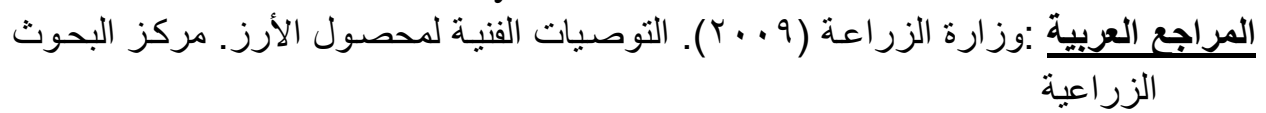
الملخص العربيى

\section{تظوير نظام نقل الحركة فى جهاز القطع لكومباين حصاد الأرز}

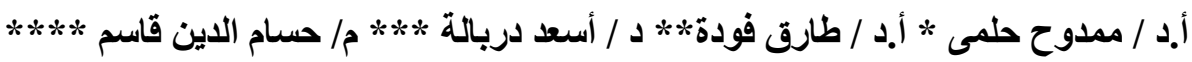

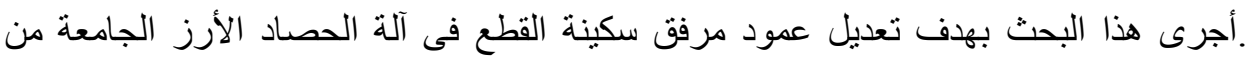

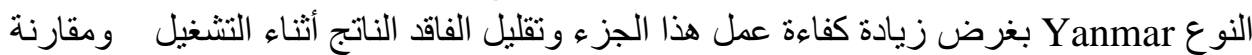

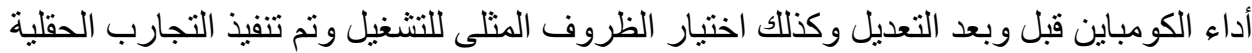

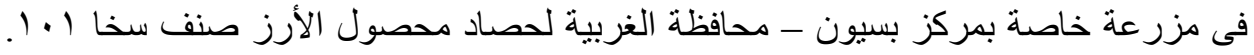

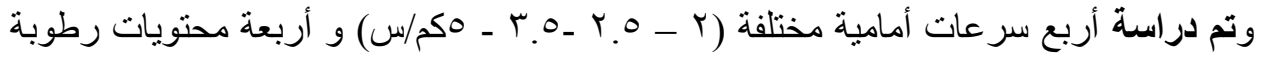

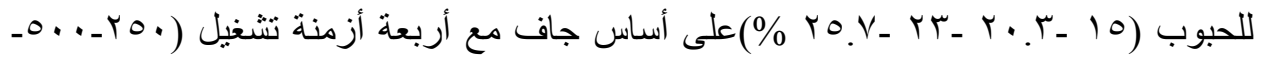

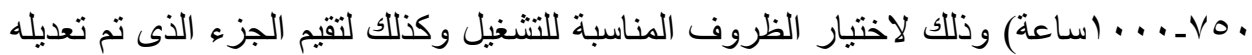

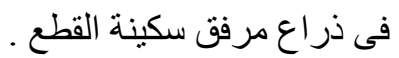
وتم قياس كل من فو اقد عدم القطعـ فو اقد الحبوب الكلية ـ السعة الحقليةـ الكفاءة الحقليةـ القدرة

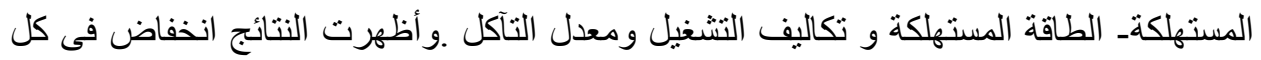

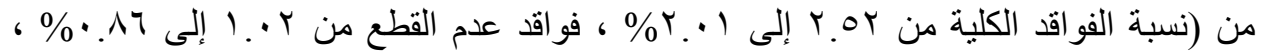

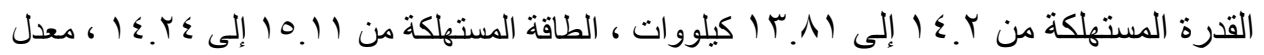

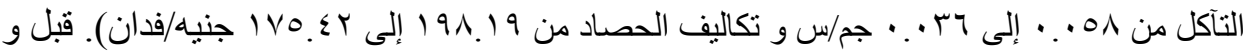

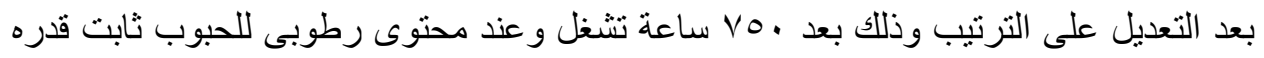

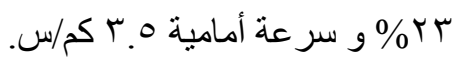

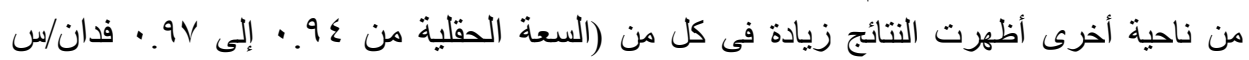

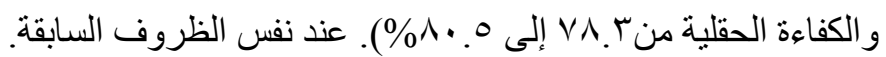

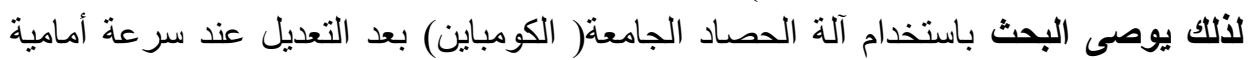

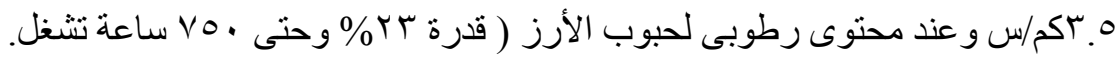

* أستاذ الهندسة الزر اعية المتفرغ - كلية الزر اعة - جامعة كفر الثيخ

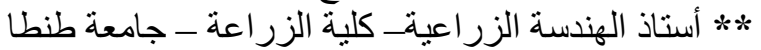

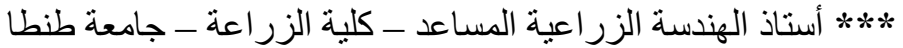

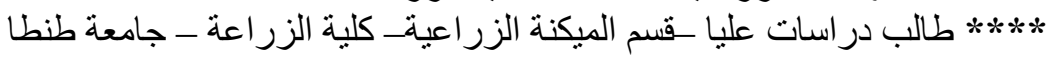

